\title{
Effectiveness of University Research Policy in Promoting Research Engagement among Accounting Academics in Public Universities in KwaZulu-Natal
}

\author{
Zwelihle Wiseman Nzuza and Lawrence Mpele Lekhanya
}

\begin{abstract}
Previous studies have shown that, until recently, few accounting academics have engaged actively in research. This study aimed to determine the effectiveness of a university research policy in promoting such engagement, with specific reference to public universities in KwaZulu-Natal, South Africa. It targeted all accounting academic staff members and was descriptive, crosssectional and quantitative in nature. Quantitative data was gathered from 82 respondents and the data were analysed using descriptive and inferential statistics. The study found that the strategies set out in university research policies are effective in encouraging accounting academics to engage in research.
\end{abstract}

Key words: university research policy, accounting academic staff, research engagement

Des études précédentes ont montré que, jusqu'à récemment, peu d'universitaires en comptabilité se sont tournés activement vers la recherche. Cette étude tendait à déterminer l'efficacité d'une politique de recherche menée par les universités, qui viserait à promouvoir une telle évolution, avec une référence spécifique aux universités publiques de KwaZulu-Natal en Afrique du Sud. Cette étude descriptive, transversale

AвOUT THE AUTHORS: ZWELIHLE WISEMAN NZUZA Lecturer in the Department of Management Accounting, Durban University of Technology, South Africa. Email: zwelihlen@ dut.ac.za

LAWRENCE MPELE LeKhanYa Senior Lecturer in the Department of Public Management and Economics, Durban University of Technology, South Africa. Email: lawrencel@dut. ac.za 
et quantitative a inclus tous les membres du personnel universitaire en comptabilité. Des données quantitatives ont été regroupées à partir des 82 membres du personnel universitaire en comptabilité et les données ont été analysées en utilisant des statistiques descriptives et déductives. L'étude a conclu que les stratégies mises en oeuvre dans les politiques de recherche menées par les universités sont efficaces pour encourager les universitaires en comptabilité à se tourner vers la recherche.

\section{Introduction}

Universities' main responsibilities are to build knowledge and develop society through teaching, research and community engagement (Thomas, 20II; McIntyre, 20I7; MacIntyre, 2009, p. 349; Thomas, 2009, p. 27). However, Terblanche (20I4, p. 66) notes that many South African universities lack an effective university research policy (URP) that encourages academics to engage in research. This could explain the low levels of research produced by accounting academics in the country (Goldman, 20II, p. 38).

Cathrynne (2018, pp. 3-4) notes that, in general, research outputs in the accounting field are lower than those in disciplines such as health sciences and engineering. This raises the question of whether URP takes cognizance of the culture of accounting. University research policy has been widely recognised as one of the most effective strategies to build knowledge and skills through research (UNDP, 2006, p. 267). Nguyeni (2015, p. i) suggests that universities with a weak research culture have a responsibility to formulate or refine their research strategies in order to improve research productivity. Higher Education South Africa (HESA) (20I4, p. 6) maintains that the success of URP depends on employing experienced academic staff with PhDs, which remains problematic for public universities in South Africa.

According to Bhatti (20II, pp. 53-54), most universities succeed in URP design but fail in implementation. Singh (20II, p. II9I) observes that executive management tends to leave implementation to HODs, who receive little support from top leadership. The literature identifies several strategies to render URP more effective (Toolsee, 20II, pp. 50-5I), including aligning it with the teaching and learning strategy; developing strong customer-driven strategies as well as core competencies; establishing strong competitive priorities; designing innovative projects, and providing strong management support. Ofori and Atiogbe (2012, pp. 68-7I) add that it is important to identify core strategic research units within the institution and individual departments such as accounting. Bhatti (20II, pp. 53-54) recommends that accountancy academics should build professional relationships with stakeholders in industry and with professional bodies, in order to produce relevant research that addresses the practical issues confronting the local and global economies (Toolsee, 20II, pp. 49-5I). Kumar and Obono (20I3, p. 34) notes that URP needs to constantly adapt to changing environments, while Mbaka and Mugambi (20I4, p. 63) advise that top management should conduct ongoing quality assurance to monitor research ethics, research equipment, and the administration of government research subsidies. North-West University (20I0, p. 6) highlights the need for public universities to adopt research policies that promote specialised research. These should be supported by effective structures, processes, and administrative arrangements (Cerniauskiene, 20I4, p. 2I). Salimian, Khalili, Nazemi, and Alborz (20I2, p. I2OI8) and Cerniauskiene (20I4, pp. 20-2I) observe that the effectiveness of URP depends on the level of available human and material resources and technological development, as well as well-conceived strategic initiatives, measures and targets, and effective leadership.

It is against this background that the study investigated the effectiveness of URP in promoting research engagement among accounting academics at universities in KwaZulu-Natal (KZN), South Africa.

\section{Problem Statement}

In general, few South African accounting academics participate actively in research (HESA, 20I4; Sambumbu, 20I3; Myers, 20I2). Indeed, the South African Institute of Chartered Accountants (SAICA) expressed the view that time devoted to research would be better spent developing accounting textbooks (de Villiers and Venter, 2010).

\section{Objective}

The study's objective was to determine whether URP is effective in encouraging accounting academics to engage in research in selected public universities in KZN.

\section{Literature Review}

For too long, accounting academics have "remained embedded in their institutional environments as 'taken for-granted' actors who could not cognitively conceive alternative arrangements" (Lubbe, 20I5, p. I085). As a result, chartered accountants (CAs) are perceived to lack a research culture. Furthermore, their teaching loads prevent many South African accounting academics from pursuing doctoral studies (Lubbe, 20I5). However, de Jager et al. (2OI6) point to a recent, positive shift in the CA institutional culture in academic organisations.

Given that, “... accountancy is a human creation - just like language. [It is] a way ... of understanding the world ... and giving it purpose" (Lawrence, 2014 , p. 39), it is essential to build a culture of research and innovation in this discipline. 


\section{Relevance of Research to Accounting}

Historically, accounting played a major role in the development of cities and trade, concepts of wealth and numbers, and in the development of money and banking systems (Anderson-Gough, Grey and Robinson, I998; Angus, 20I4). Historians such as Keistar (I965) and Chatfield (I977) note that, initially, accounting systems were designed to strengthen debit and credit transactions. There was little need for financial statements because owners had direct knowledge of their businesses and could therefore, rely on basic bookkeeping procedures for information (Anderson-Gough, Grey and Robinson, I998). However, the number of corporations rapidly increased post-I820, and managers required cost and production reports, financial statements, and operating ratios, which are more complex than simple recording procedures (Cathrynne, 20I8, p. 4). This resulted in bookkeeping expanding into accounting (Mohamud and Hikmat, 20I3).

Nonetheless, some scholars still regard accounting as an application rather than a potential field for research (Nowican, 20I8; de Villiers and Venter, 20IO). Furthermore, as noted earlier, SAICA stated that time devoted to research would be better used to develop new textbooks (de Villiers and Venter, 20IO). In contrast, Syed and Veronica (20I5) assert that research is important in order to share accounting information at a standardised level that will promote knowledge development, community engagement and innovation. In this regard, accountants from around the world, including academics, practitioners, and professionals collaborated to amalgamate the best of the Generally Accepted Accounting Practice (GAAP) statements into a single global set of GAAP, or the International Financial Reporting Standards (IFRS). This called for much research (Cathrynne, 20I8, p. 4), demonstrating its relevance to this discipline. The current study thus also investigated whether KZN accounting academics' engagement in research would enhance their institution's global competitiveness.

\section{South Africa's Global Research Collaboration Policy Framework}

Mbaka and Mugambi (20I4) note that, collaboration with researchers from other countries promotes a nation's global competitiveness, enhances research quality, and benefits society. The Department of Higher Education and Training (DHET) (2OI7) has formulated a national policy to promote such collaboration and South Africa offers a variety of research opportunities to international researchers. Indeed, Randall, Rickard and Vella-Brodrick (20I4) observe that South Africa is a gateway to Africa for researchers from other countries and is also a gateway for African researchers to move around the globe. Regional policies have also been formulated to promote South African institutions as preferred partners for research and innovation.
The South African policy framework is not intended as a treatise or a handbook on internationalisation, but aims to promote internationalisation and innovation in Higher Education (Government Gazette, 20I7). The country's public universities are required to align their internationalisation policies and strategies with the framework. Randall et al. (20I4) note that it is inclusive in that it aims to bring all stakeholders on broad, including Higher Education Institutions, government departments, students, staff, national authorities and councils, and professional and voluntary associations.

The policy framework recognises that some historically disadvantaged universities have not yet achieved the desired levels of international research collaboration (Rosentreter, 20I2) which builds academics' knowledge and skills, including intercultural skills, and helps to attract talented and highly qualified people to South African universities to enhance their human capital (Government Gazette, 20I7; Centre for Leadership in Research Development, 20I2).

\section{Challenges Confronting Global Research Collaboration in South Africa}

The Centre for Leadership in Research Development (20I2) observes that South African public universities, especially those that were previously marginalised, lack innovation and global exposure. Todtling (20I4) notes that global ranking in terms of international exposure and collaboration is based on several criteria, including the quality and quantity of academic research, staff research ratings and academic reputation. South African tertiary institutions suffered an overall decline in global ratings in 2016 and 20I7, suggesting that many are unable to meet these criteria (Darroux, Jonathan, Massele and Thibeli, 20I3; Government Gazette, 20I7).

Darroux et al. (2013) assert that innovative initiatives in public universities depend heavily on staff knowledge, expertise, and commitment. South African Higher Education Institutions have struggle to attract and retain highly qualified and experienced academics (Kumar and Eyono Obono, 2013), in part due to the fact that they lack resources to offer attractive remuneration packages to staff from abroad (Darroux et al., 2013). Todtling (20I4) and the Centre for Leadership in Research Development (20I2) point out that, this results in narrow and localised research perspectives. Rosentreter (2012) observes that, innovation is one of the most powerful mechanisms to transfer new knowledge to industry and the broader society. However, it requires new education and training approaches, more funding, new technologies and infrastructure and other relevant tools (Albu and Toader, 20I2). Ravhudzulo and Runhare (20I4) are of the view that government can play a significant role in supporting public universities to achieve innovation. 
The DHET (2OI2) and HESA (2OI4) assert that South Africa was 'deprived' of innovation during the apartheid era. For instance, universities designated for African people aimed to produce passive leaders to administer ethnic political institutions. However, they gave birth to vibrant resistance movements. While the post-I994 democratic government expects that public universities will promote economic and socio-political transformation, deep-seated apartheid legacies, the state's macro-economic policies, and the constraints imposed by globalisation have led to two opposing tendencies (Ravhudzulo and Runhare, 20I4; Reddy, 2003).

On the one hand, public universities are expected to perform as viable "corporate enterprises", producing graduates to help steer South Africa into a competitive global economy. On the other, they are mandated to serve the common good and produce critical citizens for a vibrant democratic society (Ravhudzulo and Runhare, 20I4). Higher Education South Africa observes that, in order to ensure transformation, universities must build a culture of innovation that calls for the design of new curricula.

\section{Further Challenges Include:}

\section{Priority Focus}

The policy on internationalisation of university research in South African Higher Education Institutions seeks to prioritise South Africa's wellbeing followed by, where possible and relevant, that of South African Development Community members; the rest of the African continent; the global South and emerging economies; and finally, the world (Government Gazette, 20I7). This could result in foreign researchers feeling unsure about collaborating with South African public universities. Furthermore, the unavailability of research funding for foreign researchers in South Africa is of great international concern (Rey and Bawa, 20I7). According to HESA (20I4), South Africa does not aim to side-line foreign researchers, but to redress imbalances imposed on the education system by colonialism and apartheid.

\section{Legal Compliance}

Internationalisation of universities must comply with the South African Higher Education Act and other legislation as well as national priorities in foreign relations, as determined by the South African government (CHE, 20I6). These requirements might also discourage foreign researchers. For example, the DHET produces a list of approved research publications and only articles that are published in these publications will be subsidised by the state. Furthermore, the department reserves the right to recover the funds where a university has claimed and been paid such subsidies in error (Research Grant for Universities, 20I6, p. II). Chan (20I5) notes that lan- guage barriers could also discourage foreign researchers, especially those from non-English speaking countries, while Wallace (2013, p. I05) found that some foreign residents feel that South Africa's laws discriminate against them.

\section{Research Complementarity and Value Creation}

Complementarity exists when research at both partner universities improves due to collaboration (HESA, 20I4). According to the Council on Higher Education (CHE) (2OI7), activities related to the internationalisation of Higher Education aim to create value for the parties involved, including development of knowledge and capacity, as well as cultural enrichment. However, historically disadvantaged South African universities with few resources might struggle to compete with those abroad.

Activities related to the internationalisation of university research must meet high quality standards (CHE, 20I6). Once again, this requires sufficient resources (The South African Government News Agency, 20I7).

The survival of universities depends on their capabilities which are a reflection of their ability to take full advantage of the resources available (Adeagbo, 20I6). This calls for South African universities to be competitive in terms of their curriculum design; professional accreditation of their programmes; staff skills; knowledge; innovation; investment, including the infrastructure and size of the university; research output and quality; and student enrolment and throughputs (DHET, 20I2). Thus, historically advantaged universities have a competitive edge (Hurley, 20I3).

\section{Institutional Research Policy Approaches in Public Universities}

Numerous scholars note that, employee attitudes influence the policy approaches adopted by an organisation. Policy can be planned or deliberate; emergent; opportunistic; imposed; and realised or unrealised (CHE, 20I6; Singh, 20II; Andrews, I979).

A planned policy approach is a top-down one. Information is gathered, scrutinised and analysed, with predictions made, after which senior management decides on value adding operations (De Boer and Goedegebuure, 2007; Toma, 2007; Martinet, 2010). Defined targets, timeframes and allocation of tasks are set out in writing.

Emergent policy is often informal and is not always written down. It occurs at different times as part of the university culture and can take the form of a top-down or bottom-up decision (Papagiannakis, Voudouris and Lioukas, 20I3; Martinet, 20I0). This policy approach is rare in public universities, where research policies are generally formal and documented (Johannes et al., 20I2; Lok, Rhodes and Cheng, 2010).

Opportunistic policy can result in public universities making significant 
gains (Lok et al., 20Io). Due to rapid change at the global level, public universities are compelled to modify their international research policy to take into account new skills, technologies, and related infrastructure (Singh, 20II). However, Victoria University (2009) and Li and $\mathrm{Hu}(2008)$ are of the view that only well-resourced public universities can adopt an opportunistic research policy approach as it requires new skills and fresh technologies. The CHE (20I7) notes that, one notable policy that management has imposed on academic staff is that they must be research productive without revisiting old academic workloads, especially at universities of technology where research was not previously part of the academic workload.

A successful policy is referred to as realised, whereas a failed one is unrealised (Andrews, I979; CHE, 20I7). The many reasons for unrealised policy include failure to consider influential factors depending on the university structure, nature, size, and resources (Lok et al., 20I0). This study aimed to fill the gap pertaining to the extent to which international research policy is realised among accounting academic staff at KZN public universities (Ngibe, 20I5; Mohamed, 2014).

\section{Characteristics of Effective URP}

Johannes et al. (20I2) note that URP aims to leverage and shape research and innovation in a university. It seeks to promote research among a broad range of disciplines. Effective URP is important not only for academics, but for industry. Lubbe (20I3) states that academic research does not aim to change accounting principles in industry, but to improve practitioner understanding of accounting applications. Guthrie, Burritt and Elaine (2OII) assert that the ultimate purpose is to improve accounting practice, rather than to simply describe, understand or comment on it. The South African Institution of Chartered Accountants notes that, the accounting profession is made up of two major parts, namely, policy and practice (Singleton-Green 2010 cited by Institute of Chartered Accountants in Australia, 20II). Thus, research should seek to standardise accounting treatment (English, Guthrie, Broadbent and Laughlin, 2012; Angus, 20I4).

According to Deegan and Unerman (2006) there is also a link between research and community engagement. Hopwood (2009); Guthrie, Burritt and Elaine (20II); and Bricker and Previts (I990) observe that, while universities are known for teaching jargon, URP has the potential to bridge knowledge gaps between universities and communities. Mouton (I996, cited by van der Schyf, 2008) is of the view that URP promotes the advancement of applied knowledge, which will enhance a country's socio-economic development. Finally, scholars (Oxford University, 20I7; Ofori and Atiogbe, 2OI2) note that sound URP will generate financial resources to sustain a university's global research infrastructure and other research activities.
The University of Johannesburg (2016) observes that researchers benefit from research subsidies and grants, including research awards. However, Toolsee (20II) highlights that research investment is not purely financial, but includes nurturing postgraduate students to become the next generation of research and innovation leaders.

Chan (20I5) states that URP should prioritise research on key global themes and subject areas of long-term worth. Northcott and Linacre (2013) propose that such policies should inspire academics to engage in ambitious projects, thus increasing the quality and extent of research collaborations. According to Cornelia and Christian (20I3), URP should provide strategic support to academic departments by focusing on areas where the need is greatest as well as those that promote the university's strategic goals.

The DHET (20I5, pp. I7-27) is of the view that URP should promote original, significant, and rigorous research. The University of South Africa (Unisa) (20I7) adds that it should enhance academics' creative autonomy in order to enable them to claim their place on the global research stage. The researcher or research group should decide on projects (Gopalkrishna, 20I0).

\section{Methodology}

The study targeted all accounting academic staff members in KZN public universities and was descriptive, cross-sectional and quantitative in nature, with a non-probability sample.

\section{Sample}

The respondents consisted of 82 accounting academics from the four public universities in KZN as shown in Table I below.

Table 1. Universities at which the Respondents were Employed

\begin{tabular}{|c|c|c|c|}
\hline & & Frequency & Percent \\
\hline \multirow[t]{5}{*}{ Valid } & DUT & 40 & 48,8 \\
\hline & MUT & 8 & 9,8 \\
\hline & UKZN & 27 & 32,9 \\
\hline & UNIZULU & 7 & 8,5 \\
\hline & Total & 82 & 100,0 \\
\hline
\end{tabular}

The table shows that, $40(48.8 \%)$ of the 82 respondents were from Durban University of Technology (DUT), 27 (32.9\%) were from the University of KwaZulu-Natal (UKZN), 8 (9.8\%) were from Mangosuthu 
University of Technology (MUT), and 7 (8.5\%) were from the University of Zululand (UNIZULU). Thus, DUT and UKZN have the highest number of accountancy academic staff, and MUT and UNIZULU have the fewest. Both UNIZULU and MUT are experiencing numerous challenges relating to staff capacity and development, while DUT and UKZN are the product of mergers, and thus have more staff (DUT, 20I8; UKZN, 20I8).

Research Instrument and Data Collection

Data were collected by means of a questionnaire, with an email sent to the respondents containing a link to the survey. It included a section on biographical data and one on the challenges confronting URP implementation in the accounting academic departments. The variables in the latter section were measured using a 5-point Likert scale. The survey was sent to 98 accounting academics and 82 responded, representing a response rate of $84 \%$. An online survey method was also used for the pilot study and the five respondents were given five days to comment on the questionnaire. The pilot study identified unclear and vaguely formulated statements.

\section{Data Analysis}

The data were analysed using descriptive statistics and chi square goodness of fit test (at a level of significance $\mathrm{p}=0.05$ ). This enabled the researchers to determine how the variables related to one another and whether there were any differences between them.

\section{Research Results}

\section{Reliability and Validity}

The reliability tests performed were conclusive for all the questionnaire items (Cronbach's alpha $>0.5$ ). Reliability tests were performed with a confidence level of 0.950 ; thus, the reliability of the study was acceptable. All the statements in the questionnaire were tested through a pilot study for face validity and ambiguous statements were corrected.

\section{Biographical Information}

The biographical information includes the respondents' work experience and academic qualifications.
Figure 1. Work Experience

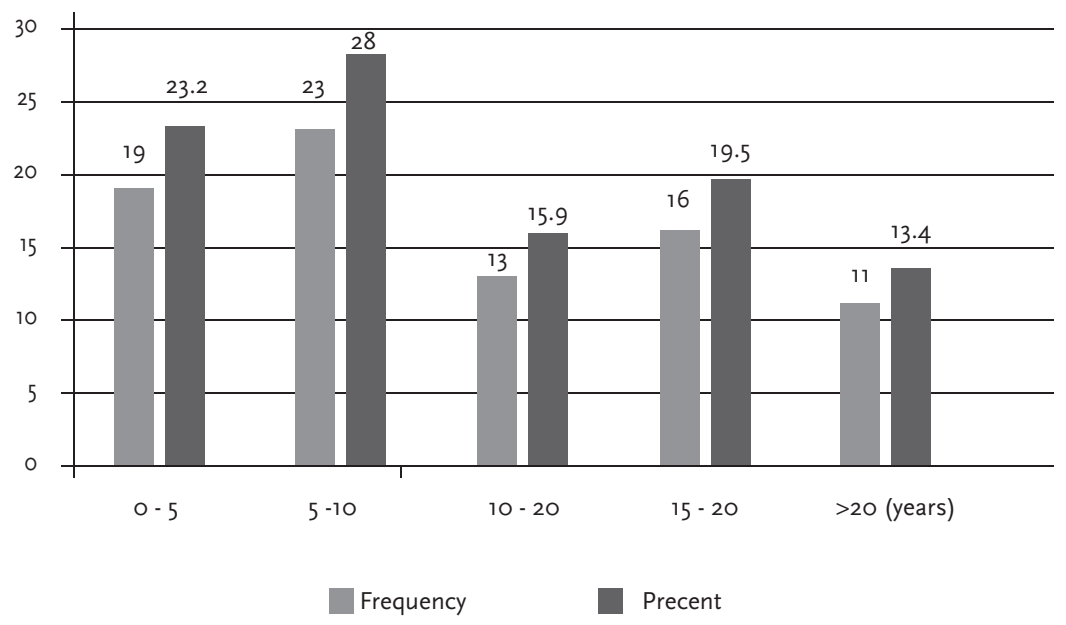

Figure I shows that, 23 of the 82 respondents (28\%) had between 5 and Io years' experience, I9 (23.2\%) had 0-5 years, I6 (I9.5\%) had I5-20 years, I3 (I5.9\%) had IO-I5 years, and II (I3.4\%) had 20 and more years' experience.

\section{Figure 2. Qualifications}

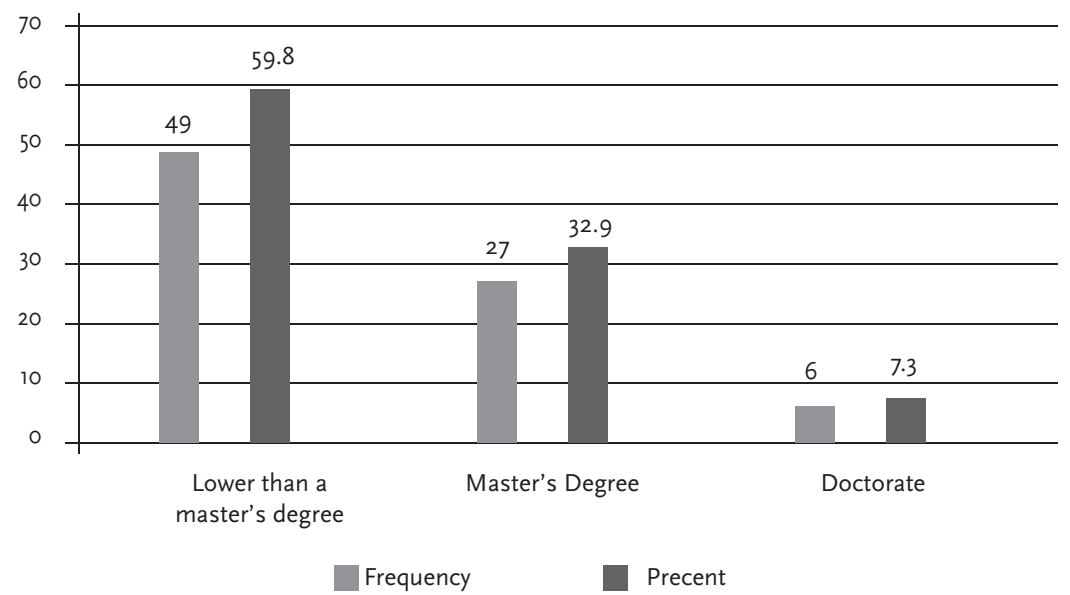


Figure 2 reveals that, of the 82 respondents, 49 (59.8\%) held a degree at a lower level than a master's qualification, 27 (32.9\%) had a master's degree, and $6(7.3 \%)$ had a PhD.

Effectiveness of URP

The findings on the perceived effectiveness of URP in promoting research among accounting academics are shown in Table 2 . This is followed by a summary of the most significant findings.

A mean group comparison test was performed to determine if there are significant differences in the effectiveness of URP. The mean result for statement 4 , 'URP delivers innovative research to industry' is 2.89 , which is close to 3, meaning that most of the respondents remained neutral in relation to this issue. This suggests that there is poor research collaboration between the accounting academics and industry.

Most of the respondents agreed with the remaining statements. These results suggest that URP strategies are effective in promoting accounting academics' engagement in research and that the policy is motivational and user friendly.

Furthermore, all the statements are significant for the effectiveness of URP at Sig.0.000.
Table 2. Effectiveness of URP

\begin{tabular}{|c|c|c|c|c|c|}
\hline Questionnaire Atatement (QS) & $\begin{array}{l}\text { QS } \\
\text { Number }\end{array}$ & Mean & $\begin{array}{l}\text { Chi- } \\
\text { Square }\end{array}$ & Df & $\begin{array}{l}\text { Asymp. } \\
\text { Sig. }\end{array}$ \\
\hline URP allows me to engage in research. & 1 & 2.05 & 22.78 & 3 & 0.000 \\
\hline $\begin{array}{l}\text { URP promotes global research that is recognised by } \\
\text { accounting professions. }\end{array}$ & 2 & 2.2 & 27.827 & 4 & 0.000 \\
\hline URP advances research in accounting education. & 3 & 1.89 & 53.732 & 4 & 0.000 \\
\hline URP delivers innovative research to industry. & 4 & 2.89 & 9.098 & 4 & 0.059 \\
\hline $\begin{array}{l}\text { URP delivers innovative solutions to our partners in } \\
\text { the wider community. }\end{array}$ & 5 & 2.79 & 8.732 & 4 & 0.068 \\
\hline URP builds the financial strength of my department. & 6 & 2.11 & 38.976 & 4 & 0.000 \\
\hline $\begin{array}{l}\text { URP promotes a departmental culture that } \\
\text { recognises and supports the development of the } \\
\text { widest possible range of high-quality research. }\end{array}$ & 7 & 1.93 & 71.78 & 4 & 0.000 \\
\hline $\begin{array}{l}\text { URP helps accounting academics to establish } \\
\text { themselves as key partners of choice for research } \\
\text { collaborations at a global level. }\end{array}$ & 8 & 2.02 & 45.927 & 4 & 0.000 \\
\hline $\begin{array}{l}\text { URP provides for continuous improvement of staff } \\
\text { research profile. }\end{array}$ & 9 & 1.79 & 41.805 & 3 & 0.000 \\
\hline $\begin{array}{l}\text { URP nurtures postgraduate researchers to become } \\
\text { the next generation of accounting researchers and } \\
\text { innovation leaders. }\end{array}$ & 10 & 1.8 & 71.293 & 4 & 0.000 \\
\hline $\begin{array}{l}\text { URP attracts a talented workforce to service the } \\
\text { department and the School of Accountancy. }\end{array}$ & 11 & 2.07 & 42.39 & 4 & 0.000 \\
\hline $\begin{array}{l}\text { URP attracts a diverse workforce to service the } \\
\text { accounting department. }\end{array}$ & 12 & 2.01 & 60.073 & 4 & 0.000 \\
\hline $\begin{array}{l}\text { URP helps my department to be productive in its } \\
\text { core academic activities. }\end{array}$ & 13 & 2.18 & 30.561 & 4 & 0.000 \\
\hline $\begin{array}{l}\text { URP promotes a more unified and shared education- } \\
\text { al experience among accounting academics. }\end{array}$ & 14 & 2 & 42.756 & 4 & 0.000 \\
\hline $\begin{array}{l}\text { URP increases the quality and extent of research } \\
\text { collaboration in the university's research focus areas. }\end{array}$ & 15 & 1.98 & 22 & 3 & 0.000 \\
\hline URP seeks to enrich individual academics. & 16 & 1.99 & 48.366 & 4 & 0.000 \\
\hline $\begin{array}{l}\text { URP enables a research training environment by } \\
\text { blending research, teaching and service. }\end{array}$ & 17 & 1.96 & 55.073 & 4 & 0.000 \\
\hline $\begin{array}{l}\text { URP has the potential to provide my department } \\
\text { with access to world-class research infrastructure. }\end{array}$ & 18 & 2.22 & 25.317 & 4 & 0.000 \\
\hline URP builds research leadership in my department. & 19 & 2.1 & 44.22 & 4 & 0.000 \\
\hline
\end{tabular}

Note: $1=$ Strongly Agree, $2=$ Agree, $3=$ Neutral $4=$ Disagree, $5=$ Strongly Disagree 
Table 3. Effectiveness of URP

\begin{tabular}{|c|c|c|c|}
\hline Rotated Component Matrix & \multicolumn{4}{|l|}{} \\
\hline \multirow{2}{*}{$\begin{array}{l}\text { Questionnaire Statement } \\
\text { Number }\end{array}$} & 1 & 2 & 3 \\
\hline 1 & -0.074 & 0.091 & 0.783 \\
\hline 2 & 0.246 & 0.092 & 0.696 \\
\hline 3 & 0.421 & -0.042 & 0.673 \\
\hline 4 & -0.111 & 0.028 & 0.738 \\
\hline 5 & -0.319 & 0.269 & 0.651 \\
\hline 6 & 0.182 & 0.795 & 0.144 \\
\hline 7 & 0.663 & 0.620 & 0.061 \\
\hline 8 & 0.424 & 0.691 & 0.178 \\
\hline 9 & 0.643 & 0.521 & 0.222 \\
\hline 10 & 0.541 & 0.691 & 0.070 \\
\hline 11 & 0.795 & 0.276 & 0.209 \\
\hline 12 & 0.669 & 0.371 & 0.019 \\
\hline 13 & 0.870 & 0.188 & -0.044 \\
\hline 14 & 0.853 & 0.200 & 0.144 \\
\hline 15 & 0.870 & 0.130 & -0.024 \\
\hline 16 & 0.761 & 0.397 & -0.118 \\
\hline 17 & 0.862 & 0.136 & 0.028 \\
\hline 18 & 0.707 & 0.243 & -0.131 \\
\hline 19 & 0.850 & 0.320 & -0.006 \\
\hline
\end{tabular}

Extraction Method: Principal Component Analysis

Rotation Method: Varimax with Kaiser Normalization

a. Rotation converged in six iterations

Factor analysis was used to establish whether the statements in each theme measured the same thing. As shown in Table 3 above, the variables were split along I, 2 and 3 components and were combined to create new themes. The questions that loaded highly on factor I all seem to relate to using URP to promote a research culture in the university. Therefore, this factor could be labelled research culture. The Kaiser-Meyer-Olkin (KMO) values of factor I sub-variables, 'talented workforce', and 'enriching individual academics' and 'access to world-class research infrastructure' are $0.795,0.76 \mathrm{I}$ and 0.707 , respectively. Thus, the effect of research culture is strong and significant in promoting accounting academics' engagement in research. All the questions that loaded highly on factor 2 relate to different strategies to make researchers globally competitive; therefore, this factor could be labelled globally competitive research. The KMO values of factor 2 sub-variables, 'financial strength', 'research collaborations', and nurturing 'postgraduate researchers to become the next generation of accounting researchers and innovation leaders' are 0.795, 0.69I and 0.69I, respectively. This means that globally competitive research has a significant effect in promoting accounting academics' engagement in research. The five questions that loaded highly on factor 3 all relate to applied research; therefore, this factor could be labelled applied accounting research. The KMO values of factor 3 sub-variables, 'engage in research, 'research recognised by accounting professions', 'research in accounting education', 'delivers innovative research to industry', and 'delivers innovative solutions to the community' are $0.783,0.696,0.673,0.738$ and 0.651 , respectively. This implies that the respondents consider applied research as the most important factor in promoting accounting academics' engagement in research.

\section{Conclusion}

University research policies set strategic goals for research conducted under the auspices of Higher Education Institutions. This article examined the effectiveness of URP in promoting engagement in research among accounting academics in public universities in KZN. The data were gathered by means of a survey of accounting academics at four public universities in the province. Most of the respondents chose to remain neutral in response to the statement that URP delivers innovative research to industry. Despite this, they were hopeful that URP would assist them in participating in research projects that will improve their relationship with industry. It was also found that the respondents perceived URP as an instrument to promote globally recognised research that delivers innovative solutions to the wider community, while fostering a departmental culture that recognises and supports development of the widest possible range of high-quality research. The results show that all statements are significant for the effectiveness of URP at Sig.0.000. It is recommended that the KZN public universities should periodically assess URP's effectiveness in promoting engagement in research among accounting academics. Furthermore, they should undertake an on-going strategic accounting research planning process that defines quantifiable targets and establishes clearly stated tasks and responsibilities. Identified problems should be addressed and necessary adjustments should be made. Further research is also recommended on URP design and implementation challenges in the accounting cluster in public universities. 


\section{Limitations of the Study}

This study was confined to accounting academic departments in KZN public universities. Expanding its scope with larger samples and different methodologies would offer a more holistic picture of URP.

\section{References}

Albu, C. N., and Toader, S. (20I2). Bridging the gap between accounting academic research and practice: some conjectures from Romania. Accounting \& management information systems / contabilitate si informatica de gestiune 11(2), I63-165.

Anderson-Gough, F., Grey, C., and Robson, K. (I998). Making up accountants: the organizational and professional socialization of trainee chartered accountants. In association with the Institute of Chartered Accountants. London, UK: Ashgate.

Andrews, K. (I979). Teenagers' attitudes about art museums. Curator: the museum journal banner 22(3), 224-228.

Angus, O. U. (20I4). Theories of accounting: evolution \& developments, Income-determination and diversities in use. Research journal of finance and accounting, 5(19), I-4.

Baijnath, N., and Barnes, T. (20I0). The development of restructuring policywithspecialreferencetocomprehensiveinstitutions.Available:https: //www.semanticscholar.org/paper/The-development-of-restructuring -policy\%2C-with-to-Baijnath-Barnes/fi76a4b5od6515fid7f55a34ebbf2 Geo8eb4223c (Accessed 22 September 2019).

Bhatti, K. K. (20II). Effect of direct participation on organizational commitment. International journal of business and social science 2(9), 53-54.

Bricker, R. J., and Previts, G. J. (I990). The sociology of accountancy: a study of academic and practice community schisms. Accounting horizons 4(I), 4 .

Cathrynne, L. S. (20I8). Gripping GAAP. Butterworth Publishers (Pty.) Ltd, South Africa.

Cerniauskiene, N. (20I4). Strategic management of public sector institutions: student workbook. Available: http://www.esparama.lt/es_ parama_pletra/failai/ESFproduktai/20I4_Strategic_Management_of_ Public_Sector_Institutions.pdf.pdf. (Accessed 22 July 20I6).

Chan, J. (20I5). International research collaboration growing but still hard to measure. Academic leaders talk about why at the times higher education world academic summit at the university of Melbourne. Available: https://www.elsevier.com/connect/international-research-collaboration-growing-but-still-hard-to-measure (Accessed ir September 20I9).

Chisholm, H. (2009). The encyclopaedia Britannica: a dictionary of arts, sciences, literature and general information. $\mathrm{II}^{\text {th }}$ ed. Harvard: Encyclopaedia
Britannica.

Cornelia, G., and Christian, K. (20I3). The challenges of strategic management in the twenty-first century. Available: https://link.springer.com/ chapter/Io.1007/978-3-658-02875-6_2 (Accessed io September 2015).

Council on Higher Education (CHE). (20IO). Annual report of the council on higher education 2010/20II. Available. https://www.che.ac.za/ media_and_publications/annual-reports/annual-report-councilhigher-education-201020II. (Accessed 22 September 2018).

CHE. (20I3). CHE annual report 20I2-20I3. Available: http://www.che. ac.za/sites/default/files/publications/CHE\%2oAnnual\%2oRep rt\%2020I2_20I3.pdf (Accessed 22 September 20I8).

CHE. (20I6). Quality enhancement project: institutional reports; phase I. Available: www.che.ac.za/.../content-analysis-baseline-institutionalsubmissions-phase-I-quality (Accessed o7 September 20I8).

CHE. (2OI7). Quality enhancement project: institutional feedback report. Available: www.che.ac.za/sites/default/files/final\%2oqep\%2oreport2ocut.pdf (Accessed o7 September 2018).

Darroux, C., Jonathan, H., Massele, J., and Thibeli, M. (2013). Knowledge management the pillar for innovation and sustainability. International journal of sciences: basic and applied research 9(I), II4.

De Boer, H., and Goedegebuure, L. (2007). Modern governance and codes of conduct in Dutch higher education. Higher education research 26(I), 47.

Deegan, C., and Unerman, J. (2006). Financial accounting theory. $\mathrm{I}^{\text {st }} \mathrm{ed}$. European: McGraw-Hill Education.

De Jager, P. Lubbe, I., and Papageorgiou, E. (20I7). The South African Chartered Accountant Academic: Motivations and Challenges when Pursuing a Doctoral Degree. Meditari Accountancy Research 26(2), io.

De Villiers, C., and Venter, E. (20I0). The effect of the accounting profession on the academy: a cautionary case study. Available: http://apirazoro. econ.usyd.edu.au/conference_proceedings/APIRA-20I0-I95-deVilliers-The-accounting-professions-affect-on-academe.pdf. (Accessed I4 October 20I6).

DHET. (20I2). Green paper for post-school education and training. Pretoria: department of higher education and training. Available: http://www.saqa.org.za/docs/papers/20I2/greenpaper.pdf (Accessed o8 February 2016).

DHET. (20I5). Report on the evaluation of the 2013 universities' research outputs. Available: www.dhet.gov.za/.../Report\%20of\%202013\%20 Research\%20Outputs.pd (Accessed I4 May 20I5).

DHET. (20I7). Research agenda 20I7-2020. Available: www.dhet.gov.za (Accessed I4 September 2018). 
Du Pre, R. (2009). South African technology network (SATN): the place and role of universities of technology in South Africa. Bloemfontein: Durban University of Technology on behalf of the South African Technology Network.

DUT. (20I8). Durban University of Technology research strategic plan: 20I4-2018. Available: www.dut.ac.za/wp-content/uploads/20I5/II/ Research-Strategic-Plani.pdf (Accessed I7 September 20I8).

DUT. (2008). Years of wisdom. Available: http://www.dut.ac.za/wp-content/uploads/menu/DUT_ioo.pdf (Accessed 05 May 20I8).

English, L., Guthrie, J., Broadbent, J., and Laughlin, R. (20I2). Performance audit of the operational stage of long term partnerships for the private sector provision of public services. Australian accounting review 20(I), $64-75$.

Fielden, J. (2008). Global trends in university governance. The World Bank education working paper 9(I), 65 .

Goldman, M. (20II). Speculative urbanism and the making of the next world city. International journal of urban and regional research 35(3), 38 .

Gopalkrishna, C. (20I0). The transformation of the South African higher education sector through mergers - the case study of the Durban University of Technology. D.Tech. in Human Resources Management, Durban University of Technology.

GovernmentGazette.(20I7). Republic of South Africa. Available:http://www. treasury.gov.za/documents/national\%2obudget/20I7/4087I_30-520I7_DivisionOfRevenueAct3of20I7.pdf (Accessed 22 July 20I7).

Guthrie, J., Burritt, R., and Elaine, E. (20II). Bridging the gap between academic accounting research and professional practice. Available: https://www.charteredaccountants.com.au/ /media/files/news\%20 and\%2omedia/03II-53\%2obridging\%2othe\%2ogap\%2opublicationcomplete.ashx (Accessed ig June 2015).

HESA. (20I4). South African higher education in the 2oth year of democracy: context, achievements and key challenges. Available: www. hesa.org.za/.../hesa_portfolio\%2ocommittee\%2opresentation_5\% (Accessed o5 April 20I5).

Hopwood, A. G. (2009). Whither accounting research?' Accounting review $82(5), 1365$.

Institute of Chartered Accountants in Australia. (20II). The relationship between academic accounting research and professional practice. Available: http://www.slideshare.net/charteredaccountants/bridgingthe-gap-between (Accessed o8 August 20I4).

International Federation of Accountants (IFAC) (2019). South African Institute of Chartered Accountants. Available: https://www.ifac.org/ about-ifac/membership/members/south-african-institute-of-char- tered-accountants. (Accessed II September 20I9).

Johannes C. B., Philipp, S., Vicki, G. M., and Russell, S. W. (20I2). Managerial decision making in customer management: adaptive, fast and frugal? Available: http://web.a.ebscohost.com/ehost/pdfviewer/pdfviewer?sid =I92275e5-bo3f-4245-848e-db96f2ab7ibb\%40sessionmgr4002 \&vid=6\&hid=4I06 (Accessed II September 2015).

King, C. (20I7). World-Class universities: understanding the attributes, pursuing the stature. Available: http://stateofinnovation.com/worldclass-universities understanding-the-attributes-pursuing-the-stature (Accessed 8 September 20I7).

Kip Holderness, D., Noah, J. R., Myers, M., Scott, L. S., and Wood, D. A. (20I4). Accounting education research: ranking institutions and individual scholars. Issues in accounting education 29(I), 87.

Kumar, S. K., and Eyono Obono, S. D. (20I3). Examining the perceived impact of ICT adoption on academic workload and on academic productivity. International journal of information and education technology 3(I), 34 .

Lawrence, S. (20I4). Super-vision? Personal experiences of an accounting academic. Meditari Accountancy Research 22(I), 38-53.

$\mathrm{Li}, \mathrm{Y}$., and Hu, J. (2008). An empirical research on the patterns and affecting factors of strategy formation processes. Frontiers of business research in China 2(2), 2010-2011.

Lok, P., Rhodes, J., and Cheng, V. (2010). A framework for strategic decision making and performance among Chinese managers. The international journal of human resource management 21(9), I377-I379.

Lubbe, I. (2013). Educating accounting professionals: development of a theoretical framework as a language of description of accounting knowledge production and its implications for accounting academics at South African universities. South African journal of accounting research 27(I), IIO.

Lubbe, I. (2OI5). Educating professionals: perceptions of the research-teaching nexus in accounting (a case study). Studies in Higher Education 40(6), 1085-1106.

MacIntyre, A. (2009). The very idea of a university: Aristotle, Newman and us. British Journal of Educational Studies 57(4), 349.

Martinet, A. C. (20I0). Strategic planning, strategic management, strategic foresight: the seminal work of $\mathrm{H}$. Igor Ansoff. Technological forecasting and social change 77(9), I48I-I489.

Mbaka, R. M., and Mugambi, F. (2OI4). Factors affecting successful strategy implementation in the Water Sector in Kenya. Journal of business and management $16(7), 63$.

McIntyre, G. 20I7. Academic vs professional qualifications. Available: 
https://www.bbrief.co.za/20I7/IO/3I/academic-vs-professional-qualifications / (Accessed og July 20I9).

Mohamed, F. (20I4). Perceptions of accounting academics on the relevance of accounting research for accounting theory and practice. M.Com., University of Johannesburg.

Mohamud, A., and Hikmat, A. A. (2013). The development of accounting through history. International journal of advances in management and economics 2(2), 98-99.

Musiige, G., and Maassen, P. (2009). Faculty perceptions of the factors that affect research productivity at Makerere University. Available: http:// kasetsartjournal.ku.ac.th/kuj_files/2009/A0906251543307343.pdf (Accessed i4 June 2018).

MUT. (20I5). Annual report. Available: https://www.mut.ac.za/downloads/ publications/mut-20I5-annual report/files/assets/common/downloads/mut-20I5-annual-report.pdf (Accessed I8 September 20I8).

MUT. (20I8). Historical background. Available: https://www.mut.ac.za/ historical-background/ (Accessed 5 May 20I8).

Myers, G. T. (20I2). The knowledge of, and the attitude towards, taxation of South Africans. D.Tech. in Business Administration, Durban University of Technology.

Ngibe, M. (2015). Staff and student perceptions of research structures and services provided by the faculty research offices at a university of technology in South Africa. M.Tech. in Commercial Administration, Durban University of Technology.

Nguyen, Q. H. (20I5). Factors affecting the research productivity of academics at the research-oriented university in Vietnam. Doctor of Education, Griffith University.

Northcott, D., and Linacre, S. (2013). Producing spaces for academic discourse: the impact of research assessment exercises and journal quality rankings. Australian accounting review 20(I), 38-54.

North-West University. 20I0. Latest research news. Available: http://services.nwu.ac.za/research-support (Accessed 22 September 20I8). Nowican, (20I8). Career opportunities as a CA(SA). Available: https://www.nowican.co.za/home/news-events/career-choice/careeropportunities-as-a-casa-student.html (Accessed 28 May 20I8).

Ofori, D., and Atiogbe, E. (2OI2). Strategic planning in public universities: a developing country perspective. Journal of management and strategy 3(I), 69 .

Oxford University. (20I7). Enabling strategies. Available: https://www. ox.ac.uk/ about/organisation/strategic-plan/enabling- (Accessed I8 June 20I7).

Papagiannakis, G., Voudouris, I., and Lioukas, S. (20I3). The road to sus- tainability: exploring the process of corporate environmental strategy over time. Business strategy and the environment 23(4), 257.

Randall, W. M., Rickard, N. S., and Vella-Brodrick, D. A. (20I4). Emotional outcomes of regulation strategies used during personal music listening: a mobile experience sampling study. Available: http://journals.sagepub.com/doi/abs/Io.II77/IO298649I4536430 (Accessed io October 20I8).

Ravhudzulo, A., and Runhare, T. (20I4). The social reproductive role of Christian missionary education in apartheid South Africa: evidence from history and research. Zimbabwe journal of educational research $26(\mathrm{I}), 4$.

Renard, M. (20I5). Correlating non-profit employees' levels of salary satisfaction with their intrinsic rewards: A South African study. African journal of reward 1(I), 63-70.

Research grant for universities. (20I6). Ministerial statement on university funding: 20I7/18 and 20I8/I9. Available: www.dhet.gov.za/.../I6I2I4 ministerialstatement.pdf (Accessed 6 January 2020).

Research in science innovation technology and engineering (SITE) and gender round table. (2OI7). DUT co-hosts site and gender round-table. Available: www.dut.ac.za/dut-co-hosts-research-in-science-innovationtechnology-and-(Accessed I4 March 20I9).

Rey, C., and Bawa, A. (20I7). Universities SA expresses concern over cuts to funding for research development. Available: https://www.news. uct.ac.za/article/-20I7 II-29-universities-sa-expresses-concern-relating -to-the-cuts-in-funding-for research-development (Accessed 9 November 20I9).

Rosentreter, S. J. (2012). Towards improving research among cost and management accounting academics at universities of technology: a study of South Africa and Germany. M.Tech. in Cost and Management Accounting, Durban University of Technology.

Salimian, H., Khalili, S., Nazemi, J., and Alborzi, M. (2012). Alignment in the organisation's strategy window (concentration on business strategy andoperations strategy). African journal of business management 6(5I), I20I8.

Sambumbu, M. (2013). Lecture guide; human resource management. University of Fort Hare. Available: www.ufh.ac.za/centres/fhs/sites/ default/files/ Course\%20Brochure\%2020I3-7. (Accessed 3I March 20I5).

Samkin, G., and Schneider, A. (20I4). Using university websites to profile accounting academics and their research output. Meditari Accountancy Research 22(I), 77-106.

Singh, D. (20II). Publication bias - a reason for the decreased research 
output in developing countries. South African psychiatry review 9, II9I. Syed, Z., and Veronica, P. (2OI5). Consequences of IFRS adoption: A literature review. Journal of theoretical accounting research 10(2), II7.

Terblanche, E. A. J. (20I4). Measuring the accessibility of accountancy programmes with special emphasis on chartered accountancy in South Africa. M.Compt., University of South Africa.

Thomas, A. (2009). Internal governance imperatives for universities. African journal of business ethics 4(I), 27.

Thomas, L. (20II). Students' retention in higher education: the role of institutional habits. Journal of education policy 17(4), 513.

Todtling, F. (20I4). The role of universities in innovation systems and regional economies. Expert meeting on the future of academic research,Vienna.Available:http://www.oecd.org/innovation/research/ 37592074.pdf (Accessed I5 September 20I7).

Toma, J. D. (2007). Expanding peripheral activities, increasing accountability demands and reconsidering governance in US higher education. Higher education research a development 26(3), 58.

Toolsee, A. (20II). Successful criteria for implementing strategies within the banking industry. Master's in Business Leadership, University of South Africa.

UKZN. (20I6). Annual report. Available: https://www.ukzn.ac.za/mediapublications-reports/annual-reports/ (Accessed o6 September 2018).

UKZN. (2018). UKZN history. Available: https://www.ukzn.ac.za/aboutukzn/history/ (Accessed o5 May 2018).

UNDP. (2006). Human development report 2006. beyond scarcity: power, poverty and the global water crisis. Available: http://hdr.undp.org/ sites/default/files/reports/267/hdro6-complete.pdf (Accessed 2I June 20I8).

UNISA. (20I7). Accounting sciences research. Available: http://www. unisa.ac.za/sites/corporate/default/Colleges/Accounting-Sciences/ Research (Accessed I5 June 20I7).

University of Johannesburg. (20I6). Higher degrees' policy. Available: https://www.uj.ac.za/about/Documents/policies/Higher\%2oDegrees \%20and\%20Post\%20Graduate\%20Studies\%2oPolicy.pdf (Accessed I September 20I7).

UNIZULU. (20I8). UNIZULU history. Available: https://oldsite.unizulu. ac.za/about_history.php (Accessed 05 May 20I8).

Van der Schyf, D. B. (2008). The essence of a university and scholarly activity in accounting, with reference to a department of accounting at a South African university. Meditari accounting research 16(I), I8-19.

Vice-Chancellor's welcome address. (20I6). DUT annual research and innovation awards. Available: www.dut.ac.za/dut-celebrates-excel-
lence-at-the-20I7-annual-research-and-innovation (Accessed September 20I8).

Victoria University. (2009). Research. Available: https://www.ufv.ca/ research/ (Accessed I7 September 20I8).

Wallace, G. P. R. (2013). International law and public attitudes toward torture: an experimental study. International organization 67(I), I05. 